\title{
Phenodynamics of five orchids species growing on rock outcrops in the Chapada Diamantina Mountains in northeastern Brazil
}

\author{
Karoline Coutinho de Santana**, Isys Mascarenhas Souza', Lia d'Afonsêca Pedreira de Miranda' \\ and Ligia Silveira Funch ${ }^{1}$
}

Received: April 19, 2016

Accepted: July 21, 2016

\begin{abstract}
We evaluated the vegetative and reproductive phenological patterns of the orchids Cattleya elongata, Cyrtopodium aliciae, Epidendrum orchidiflorum, Epistephium lucidum, and Sobralia liliastrum (Orchidaceae) growing on sandstone outcrops in the Chapada Diamantina Mountains in northeastern Brazil. Phenological events were associated with abiotic factors, leaf longevity, life form, plant growth pattern, and pollination syndrome. Phenological observations were made for 18 months and followed the phenophases of: stem/pseudobulb emission, leaf flush, leaf fall, flowering, immature fruit and mature fruit. Seasonality, synchrony, and correlations between phenophases and environmental variables were tested. The orchid species demonstrated aseasonal vegetative phenologies, except for pseudobulb emission. Reproductive events were seasonal, except for flowering in E. orchidiflorum. There was high flowering overlap between the species pairs S. liliastrum and C. aliciae (dry season) and C. elongata and E. lucidum (rainy season). Dispersal occurred during both the rainy and dry seasons. The vegetative phenophases exhibited low synchrony, and were related to certain morphofunctional characters (stems/pseudobulbs, CAM metabolism). The reproductive phenophases showed high synchrony consistent with the deceit pollination strategy usually associated with the group.
\end{abstract}

Keywords: campo rupestre, flowering overlap, photoperiod, seasonality, synchrony

Seasonality and synchrony in plant phenology are traditionally associated with environmental variables, although variations in leaf and reproductive rhythms among species occupying similar environments indicate that phenological responses may also be mediated by intrinsic species attributes such as life form, plant growth pattern, leaf longevity, and dispersal and pollination modes (Williams-Linera \& Meave 2002). The Chapada Diamantina Mountains, the northern extension of the Espinhaço range in Brazil, exhibits a vegetation mosaic with campo rupestre

\footnotetext{
${ }^{1}$ Laboratório de Flora e Vegetação, DCBio, Universidade Estadual de Feira de Santana, BR 116, km 03, 44031-460, Feira de Santana, BA, Brazil "Corresponding author: karolinecoutinho@yahoo.com.br
} 
(open, rocky field vegetation) predominating above $900 \mathrm{~m}$ a.s.l. (Funch et al. 2009). Orchidaceae is one of the principal groups found in that habitat (Conceição et al. 2007a), with approximately 300 species (Brito \& Cribb 2005). This diversity is associated with morphofunctional characters such as CAM metabolism and the presence of pseudobulbs that retain water resources for metabolic activities and facilitate survival in otherwise unfavorable environments (Silveira et al. 2009; Arévalo et al. 2011). There has been a notable lack of studies addressing the phenologies of the Orchidaceae family in Brazil, and the available information is generally restricted to records of their flowering periods and floral biology (Pansarin et al. 2012; Pansarin \& Pansarin 2014). Here, we evaluated the vegetative and reproductive phenological patterns of five Orchidaceae species (Cattleya elongata Barb. Rodr., Cyrtopodium aliciae L. Linden \& Rolfe, Epidendrum orchidiflorum Salzm. Ex Linndl., Epistephium lucidum Cogn., and Sobralia liliastrum Salzm. Ex Lindl.) in an area of campo rupestre vegetation $\left(12^{\circ} 34^{\prime} 28^{\prime \prime} \mathrm{S} x\right.$ $41^{\circ} 24^{\prime} 31^{\prime \prime} \mathrm{W}$; at $614 \mathrm{~m}$ a.s.l.) in the Chapada Diamantina Mountains, where those species grow abundantly on rocky outcrops. Considering the regional seasonality, with marked rainy and dry periods (Funch et al. 2002), the relatively low availability of water in rocky mountain top microhabitats (Conceição et al. 2007b), and well-known aspects of the structure and function of orchids that allow them to exploit seasonally dry habitats (Benzing et al. 1982), we hypothesized that their vegetative phenology would exhibit pseudobulb/stem emissions and leaf flush during the rainy season, associated with life form, plant growth pattern, and leaf longevity; as their reproductive dynamics would be aggregate adjusted to the seasonality, and mode of pollination and wind dispersal of their seeds (Borba et al. 2003; Smidt et al. 2006; Spaethe et al. 2007; Vale et al. 2011).

The regional climate is type Aw by the Köppen's climate classification (Alvares et al. 2014), marked by maximum rainfall in the Austral summer (November to April), and a dry winter (July to October). The temperature, rainfall and day lengths for the region were published by Souza et al. (2012). Campo rupestre is a complex vegetation type comprising numerous microhabitats on rocky mountain tops with water and soil nutrients restrictions and soil depths that severely limit plant establishment and growth (Conceição et al. 2007). The specimens of Orchidaceae examined here $(\mathrm{n}=89)$ were growing directly on rock surfaces (C. elongata $\mathrm{n}=24$, C. aliciae $\mathrm{n}=17$, E. orchidiflorum $\mathrm{n}=18$, and $S$. liliastrum $\mathrm{n}=21$ ) and in narrow cleft microhabitats with shallow soils contained by rock walls (E. lucidum $\mathrm{n}=9$ ).

Phenological observations were made on a monthly basis from June/2009 to November/2010 on marked individuals. Individuals were considered to be distinct plants when separated from one another by approximately $1 \mathrm{~m}$. The phenophases considered were: pseudobulb/stem emission, leaf flush, leaf fall, flowering, immature fruit and mature fruit. The phenophases were recorded on a presence-absence basis. Four individuals of each species were closely accompanied during the phenological observations to determine leaf longevity by sketching them on paper and thus recording and numbering existing leaves and all new leaves. We also analyzed life forms (Raunkiaer 1934), plant growth patterns, pollination syndromes (Faegri \& Pijl 1979), and floral and inflorescence characteristics (such as color, size, the presence of nectar or oil) by observations in the field or by consulting the literature (Chingel 2001). The Shapiro and Wilk test was used to determine the normality of the distributions of the phenological and environmental data (Zar 1996). The Spearman correlation index was calculated for data that did not have normal distributions, and the Pearson correlation index was calculated for the data that showed normal distributions, using Past 2.1.7 software. The seasonality and synchrony of the phenophases in each species and the overlap in flowering species pairs were evaluated using circular statistics (Morellato et al. 2010), run on Oriana software.

Four Orchidaceae species were classified as hemicryptophytes, having rhizomes flush to the ground/ rock surface; E. lucidum was classified as a cryptophyte, as its rhizomes grow below the soil surface in narrow rock-cleft microhabitats. The orchid species all showed sympodial growth pattern, with pseudobulbs (C. elongata and C. aliciae) or stems (E. orchidiflorum, S. liliastrum, and E. lucidum) united by rhizomes; stems were numerous in E. orchidiflorum, S. liliastrum, while E. lucidum produced only a single stem. Plants with stems showed numerous leaves along the stem, with continuous leaf flush and leaf fall. Plants with pseudobulbs produced just a few apical leaves; the pseudobulbs and leaves of $C$. aliciae persisted for up 12 months; the leaves of $C$. elongata remained attached to the older pseudobulbs for periods exceeding 18 months. The orchids examined demonstrated aseasonal and asynchronous vegetative phenology during the study period, except for pseudobulb emission in C. elongata and C. aliciae and leaf fall in C. aliciae, which were seasonal and synchronous (Fig. 1, Tab. 1).

Reproductive events were markedly seasonal and synchronous (Tab. 1). There was high flowering overlap in certain species pairs, with $S$. liliastrum and $C$. aliciae flowering during the dry season $(r=0.83)$, and C. elongata and E. lucidum flowering during the rainy season $(r=$ 0.87 ); the only species that demonstrated aseasonal flowering was E. orchidiflorum (Fig. 1). S. liliastrum and E. orchidiflorum produced fruits during the dry season that matured during the rainy season; $C$. elongata, C. aliciae, and $E$. lucidum initiated fruit production during the rainy season, with maturation occurring during the dry season (Fig. 1). In general, the species demonstrated correlation of their flowering and fruiting with photoperiod and temperature (Tab. 2). Melittophily predominated, except in E. orchidiflorum, which was identified as sphingophilous. The species produced apical racemes, with up to 15 flowers, 


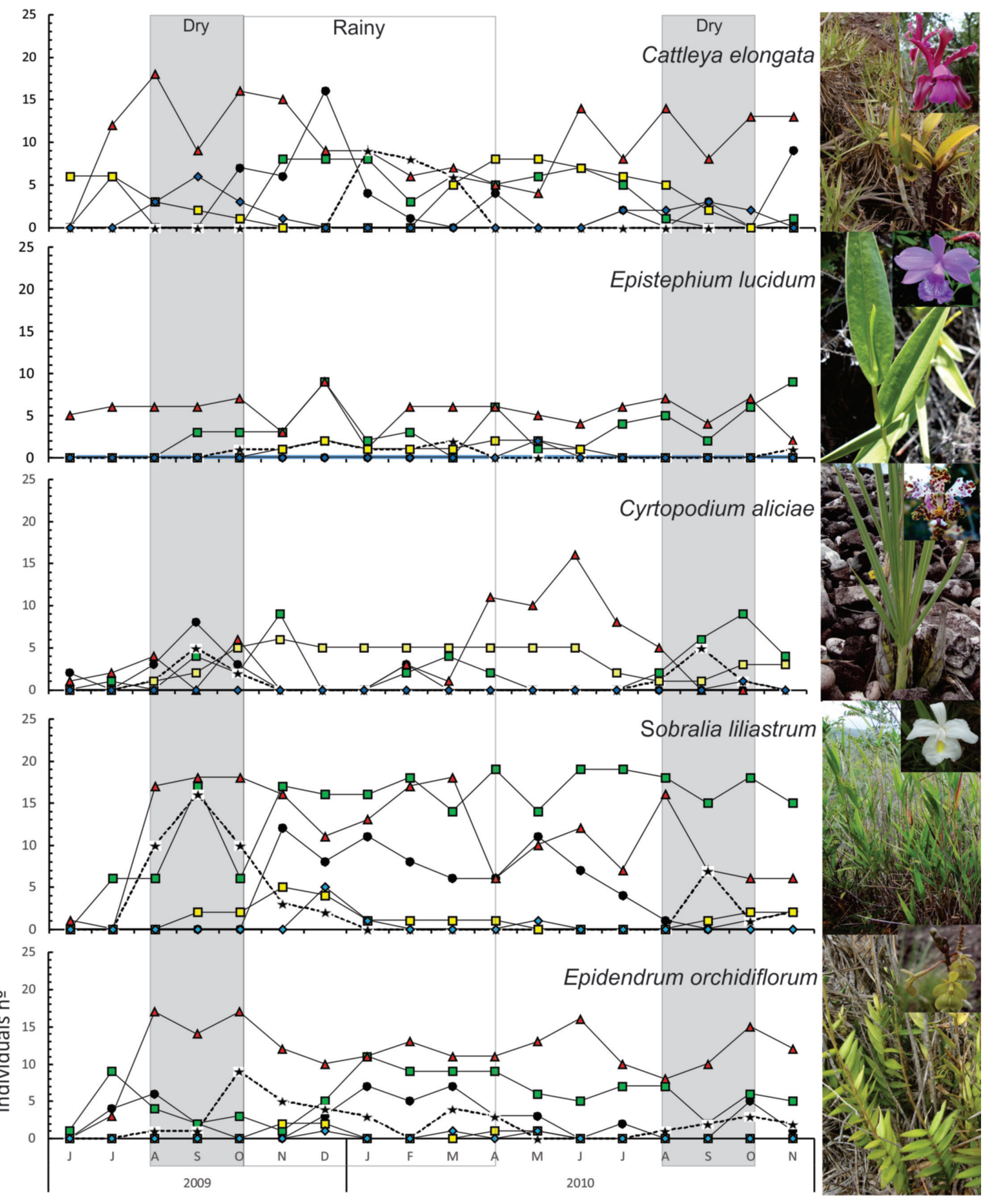

Figure 1. Habit, flower and phenology of orchids species from Chapada Diamantina, Northeast Brazil. The shaded area indicates the rainy season. Continuous lines with black circles are pseudobulbo; continuous lines with green square are leaf flushing; continuous lines with red triangles are leaf fall; dotted lines with stars are flower continuous lines with yellow square are immature fruit; continuous lines with blue rhombus are mature fruit. 


\section{Phenodynamics of five orchids species growing on rock outcrops in}

the Chapada Diamantina Mountains in northeastern Brazil

Table 1. Circular statistical analysis of the frequency of seasonal phenological phases (vegetative and reproductive) of five species of Orchidaceae, Chapada Diamantina, Northeast, Bahia, Brazil. E. pseudobulb = emission pseudobulb; E. stem = emission stem; L. flush = leaf flush; L. fall = leaf fall.

\begin{tabular}{|c|c|c|c|c|c|c|c|}
\hline Espcies & Phenophases & $\mathbf{N}^{\circ}$ Obs. & Vector mean $[\boldsymbol{\mu}]$ & Date mean & Length vector $r$ & $\begin{array}{l}\text { Standard } \\
\text { deviation }\end{array}$ & Test de Rayleigh (p) \\
\hline \multirow{5}{*}{ Cattleya elongata } & E. pseudobulb & 39 & $339.839^{\circ}$ & 09/dec. & 0.626 & $55.485^{\circ}$ & $6.31 \mathrm{e}^{-08}$ \\
\hline & L. flush & 50 & $82.911^{\circ}$ & 24/mar. & 0.328 & $85.543^{\circ}$ & 0.005 \\
\hline & L. fall & 110 & $265.985^{\circ}$ & 25/sep. & 0.177 & $106.69^{\circ}$ & $0, .032$ \\
\hline & Flowering & 23 & $45^{\circ}$ & 15/feb. & 0.925 & $22.548^{\circ}$ & $<7.31 \mathrm{e}^{-09}$ \\
\hline & Immature fruit & 41 & $150.56^{\circ}$ & 01/jun. & 0.653 & $52.916^{\circ}$ & $0.50 \mathrm{e}^{-09}$ \\
\hline \multirow{6}{*}{ Cyrtopodium aliciae } & EP & 16 & $237.626^{\circ}$ & 28/aug. & 0.578 & $74.765^{\circ}$ & 0.003 \\
\hline & L. flush & 29 & $289.687^{\circ}$ & 20/oct. & 0.427 & $74.765^{\circ}$ & 0.004 \\
\hline & L. fall & 50 & $150.579^{\circ}$ & 01/jun. & 0.737 & $44.794^{\circ}$ & $<1 \mathrm{e}^{-12}$ \\
\hline & Flowering & 7 & $255^{\circ}$ & 15/sep. & 0.973 & $13.457^{\circ}$ & $<1 \mathrm{e}^{-12}$ \\
\hline & Immature fruit & 45 & $65.935^{\circ}$ & 06/mar. & 0.266 & $93.214^{\circ}$ & 0.04 \\
\hline & Mature fruit & $* *$ & $* * * * *$ & $* * * * *$ & $* * * *$ & $* * * * *$ & $* * * * *$ \\
\hline \multirow{5}{*}{ Epidendrum orchidiflorum } & L. flush & 82 & $70086^{\circ}$ & 11/mar. & 0.177 & $106.552^{\circ}$ & 0.00054 \\
\hline & L. fall & 140 & $102.626^{\circ}$ & 13/apr. & 0.023 & $157.041^{\circ}$ & 0.926 \\
\hline & Flowering & 22 & $356.787^{\circ}$ & 26/dec. & 0.368 & $81.041^{\circ}$ & 0.049 \\
\hline & Immature fruit & 4 & $50.104^{\circ}$ & $20 /$ feb & 0.381 & $79.615^{\circ}$ & 0.591 \\
\hline & Mature fruit & 3 & $69.896^{\circ}$ & 10/mar. & 0.508 & $66.706^{\circ}$ & 0.503 \\
\hline \multirow{6}{*}{ Epistephium lucidum } & E. stem & $* *$ & ***** & $* * * * *$ & $* * * * *$ & ***** & $* * * * *$ \\
\hline & L. flush & 48 & $309.399^{\circ}$ & 09/nov. & 0.316 & $86.958^{\circ}$ & 0.008 \\
\hline & L. fall & 63 & $185.789^{\circ}$ & 06/jul. & 0.033 & $149.58^{\circ}$ & 0.933 \\
\hline & Flowering & 8 & $19.107^{\circ}$ & 20/jan. & 0.739 & $44.604^{\circ}$ & 0.016 \\
\hline & Immature fruit & 8 & $99.896^{\circ}$ & 10/apr. & 0.711 & $47.358^{\circ}$ & 0.013 \\
\hline & Mature fruit & 4 & $60^{\circ}$ & 01/mar. & 0.262 & $93.803^{\circ}$ & 0.8 \\
\hline \multirow{5}{*}{ Sobralia liliastrum } & E. stem & 65 & $74.371^{\circ}$ & 16/mar. & 0.38 & $79.747^{\circ}$ & $0.855 e^{-04}$ \\
\hline & L. flush & 201 & $187.189^{\circ}$ & 08/jul. & 0.028 & $152.887^{\circ}$ & 0.85 \\
\hline & Flowering & 12 & $280.517^{\circ}$ & 10/oct. & 0.828 & $35.189^{\circ}$ & $3.1 \mathrm{e}^{-05}$ \\
\hline & Immature fruit & 13 & $341.235^{\circ}$ & 11/dec. & 0.592 & 58.624 & 0.008 \\
\hline & Mature fruit & 7 & $356.31^{\circ}$ & 26/dec. & 0.737 & $44.78^{\circ}$ & 0.016 \\
\hline
\end{tabular}

Table 2. Correlation between phenophases and environmental variables of five species of Orchidaceae, Chapada Diamantina, Bahia, Northeast, Brazil.

\begin{tabular}{|l|c|c|c|}
\hline Species & Phenophases & Precipitation & Temperature \\
\hline Cattleya elongata & Flowering & - & - \\
\hline Cyrtopodium aliciae & Immature Fruit & -0.47 & -0.47 \\
\hline Epidendrum orchidiflorum & Immature Fruit & - & 0.71 \\
\hline Epistephium lucidum & Flowering & - & 0.39 \\
\hline Sobralia lucidum & Flowering & - & 0.67 \\
\hline
\end{tabular}

except $C$. aliciae which produces panicles with up to 300 flowers; C. elongata, E. lucidum, and S. liliastrum produce large flowers (5-8 cm diam.) and C. aliciae and E. orchidiflorum produce small flowers (1.5-3.5 cm diam.). C. elongata and $E$. lucidum produced white flowers while $C$. aliciae and $S$. liliastrum produce rose-colored blooms, and E. orchidiflorum greenish flowers (Fig. 1). Only E. orchidiflorum and E. lucidum offered nectar rewards to pollinators.

Precipitation has been recognized as the principal factor influencing plant phenological patterns in tropical environments (Brearley et al. 2007). The absence of any correlations between the phenophases and precipitation among the orchid species evaluated in the present study was probably related to the fact that they all use water resources very efficiently and demonstrate CAM metabolism (Silveira et al. 2009). The pseudobulbs/stems store water for metabolic activities and facilitate their survival in otherwise unfavorable environments (Silva \& Milaneze-Gutierre 2004); the seasonality and synchrony observed for pseudobulb emission with few apical leaves can be understood in terms 
of their construction costs, in contrast to aseasonal stem emissions with continuous leaf production and leaf fall.

The species studied demonstrated reproductive phenophases correlated with seasonal changes in photoperiod and temperature - the most predictable environmental parameters in this region. Photoperiodicity has been found to be associated with breaking and/or induction of bud dormancy, making it the trigger for growth and flowering initiation in many plant species (Stevenson et al. 2008). The high observed overlap of flowering between pairs of species with similar flower colors during the dry and rainy seasons (including E. lucidum which produces nectar) appears to be a viable reproductive strategy as most orchids mimic melittophilous flowers and, as they offer no floral rewards, are pollinated using deceit strategies (Pansarin \& Pansarin 2014). The flowers of species utilizing deceit strategies will be visited less frequently than the flowers of species that offer some type of reward (as insects have the capacity to learn) - and will consequently show less fruiting (Borba \& Semir 2001); as such, the high synchrony and overlapping between them presumably favors pollination processes by accentuating floral displays. E. orchidiflorum was the only species showing aseasonal flowering, which appears to reflect nectar production by their flowers (with characteristics of sphingophily).

A low fruiting rate is considered an adaptation among orchids, especially among epiphytic and rupiculous species, with limited access to resources; their fruits generally result from cross-pollination events and their seeds show high genetic viability - so that the production of even small numbers of fruits will allow the maintenance of viable populations (Ackerman \& Zimmerman 1994). The maturation of dry fruits is favored by dry periods with severe water restrictions, and the low relative humidity of the air contributes to their desiccation and to the dispersal of anemochoric seeds (Pezzini et al. 2008). As Orchidaceae seeds are very small and essentially without nutritional reserves their dispersal during dry periods might be expected to hinder germination and establishment, but they demonstrate dormancy due to the presence of lipidic reserves on their surfaces (which will also provide for their initial sustenance) (Baskin \& Baskin 2001), allowing dispersal in both the dry and rainy seasons.

The low intraspecific synchrony and aseasonality demonstrated by the vegetative phenophases of the orchid species examined in the present study appeared to be a reflection of the influences of the morphofunctional characters (pseudobulbs/stems and CAM metabolism), and the high synchrony and seasonality of their reproductive events is likewise related to the pollination mechanisms of the group, with overlapping of flowering among species with similar flower colors and the production of nectar by at least one of them.

\section{Acknowledgments}

The authors would like to thank Sâmia Paula Neves Oliveira for her help with the analyses; and Roy Funch and the Fundação Chapada Diamantina for the assistance during the field activities in Lençóis. This project was supported by the Fundação de Amparo à Pesquisa do Estado da Bahia (FAPESB 5303/2009).

\section{References}

Ackerman JD, Zimmerman JK. 1994. Bottlenecks in the life histories of orchids: resources, pollination, population structure, and seedling establishment. In: Pridgeon A. (ed.) Proceedings of the 14th World Orchid Conference. London, Her Majesty's Stationery Office. p.125129.

Alvares CA, Stape JL, Sentelhas PC, Gonçalves JLM, Sparovek G. 2014. Köppen's climate classification map for Brazil. Meteorologische Zeitschrif doi: 10.1127/0941-2948/2013/0507.

Arévalo R, Figueroa J, Santiago M. 2011. Anatomía foliar de ocho especies de Orquídeas epífitas. Lankesteriana 11: 39-54.

Baskin CC, Baskin JM. 2001. Seeds, Ecology, Biogeography and Evolution of Dormancy, and Germination. San Diego, Academic Press.

Benzing DH, Ott DW, Friedman WE. 1982. Roots of Sobralia macrantha (Orchidaceae): structure and function of the velamen-exodermis complex. American Journal of Botany 69: 608-614.

Borba EL, Ivo P, Braga PIS. 2003. Reproductive biology of Pseudolaelia corcovadensis (Orchidaceae): melittophyly and self-compatibility in a basal Laeliinae. Revista Brasileira de Botânica 26: 541-549.

Borba EL, Semir J. 2001. Pollinator specificity and convergence in flypollinated Pleurothallis (Orchidaceae) species: a multiple population approach. Annals of Botany 88: 75-88.

Brearley FQ, Proctor J, Suriantata, Nagy L, Dalrymple G, Voysey BC. 2007. Reproductive phenology over a 10-year period in a lowland evergreen rain forest of central Borneo. Journal Ecological 95: 828-839.

Brito ALVT, Cribb PJ. 2005. Orquídeas da Chapada Diamantina. Rio de Janeiro, Nova Fronteira.

Chingel NA. 2001. An Atlas of Orchid Pollination. Rotterdam, A. A. Balkema.

Conceição AA, Guilietti AM, Meirelles ST. 2007a. Ilhas de vegetação em afloramentos de quartzito de arenito-arenito no Morro do Pai Inácio, Chapada Diamantina, Bahia, Brasil. Acta Botanica Brasilica 21: 335-347.

Conceição AA, Funch LS, Pirani JR. 2007b. Reproductive phenology, pollination and seed dispersal syndromes on sandstone outcrop vegetation in the "Chapada Damantina" northeastern Brazil: population and community analyses. Revista Brasileira de Botânica 30: 475-485

Faegri K, Pijl L. 1979. The Principles of Pollination Ecology. 3rd. edn. Oxford, Pergamon.

Funch LS, Funch RR, Barroso GM. 2002. Phenology of gallery and montane forest in Chapada Diamantina, Bahia, Brazil. Biotropica 34: 40-50.

Funch R, Harley R, Funch LS. 2009. Mapping and evaluation of the state of conservation of the vegetation in and surrounding the Chapada Diamantina National Park, NE Brazil. Biota Neotropica 9: 1-10.

Morellato LPC, Alberti LF, Hudson IL. 2010. Applications of circular statistics in plant phenology: a case studies approach In: Keatley M, Hudson IL. (eds.) Phenological research: methods for environmental and climate change analysis. New York, Springer. p. 357- 371.

Pansarin ER, Salatino A, Pansarin LM, Sazima M. 2012. Pollination systems in Pogonieae (Orchidaceae: Vanilloideae): a hypothesis of evolution among reward and rewardless flowers. Flora 207: 849-861.

Pansarin ER, Pansarin LM. 2014. Floral biology of tow Vanilloideae (Orchidaceae) primarily adapted to pollination by euglossine bees. Plant Biology (Stuttgart) 16: 1104-1113. 


\section{Phenodynamics of five orchids species growing on rock outcrops in the Chapada Diamantina Mountains in northeastern Brazil}

Pezzini FF, Brandão D, Ranieri BD, Espírito-Santo MM, Jacobi CM, Fernandes GW. 2008. Polinizacão, dispersão de sementes e fenologia de espécies arbóreas no Parque Estadual da Mata Seca. MG Biota 1: 37-45

Raunkiaer C. 1934. The Life Forms of Plants and Statistical Plant Geography. Oxford, Clarendon Press.

Silva GI, Milaneze-Gutierre A. 2004. Caracterização morfo-anatômica dos órgãos vegetativos de Cattleya walkeriana Gardner (Orchidaceae). Acta Scientiarum 26: 91-100.

Silveira K, Santiago LSS, Cushman JC, Winter K. 2009. Crassulacean Acid Metabolism and epiphytism linked to adaptive radiations in the Orchidaceae. Plant Physiology 141: 1833-1847.

Smidt EC, Silva-Perreira V, Borba EL. 2006. Reproductive biology of two Cattleya (Orchidaceae) species endemic to north-eastern Brazil. Plant Species Biology 21: 85-91.

Souza IM, Coutinho K, Funch LS. 2012. Estratégias fenológicas de Senna cana (Nees \& Mart.) H.S. Irwin \& Barneby (Leguminosae:
Caesalpinioideae) como mecanismo eficiente para atração de polinizadores. Acta Botanica Brasilica 26: 435-443.

Spaethe J, Moser WH, Paulus HF. 2007. Increase of pollinator attraction by means of a visual signal in the sexually deceptive orchid, Ophrys heldreichii (Orchidaceae). Plant Systematics and Evolution 264: 31-40. Stevenson PR, Castellanos MC, Cortés AI, Link A. 2008. Flowering patterns in a seasonal tropical lowland forest in western Amazonia. Biotropica 40: 559-567.

Vale A, Navarro L, Rojas D, Álvarez JC. 2011. Breeding system and pollination by mimicry of the orchid Tolumnia guibertiana in western Cuba. Plant Species Biology 26: 163-173.

Williams-Linera G, Meave J. 2002. Patrones fenológicos. In: Guariguata MR, Kattan GH. (eds.) Ecologia y conservácion de bisques neotropicales. Costa Rica, Libro Uníversitario Regional. p. 407-431.

Zar JH. 1996. Biostatistical analysis. New Jersey, Prentice - Hall. 